\title{
Pisanie puszczy. Ekonomie dyskursu ekokrytycznego i postkolonialnego
}

Aleksandra Ubertowska 


\section{Dociekania}

\section{Pisanie puszczy. Ekonomie dyskursu ekokrytycznego i postkolonialnego'}

Aleksandra Ubertowska
TEKSTY DRUGIE 2017, NR 6, S. 193-208

DOI: 10.18318/td.2017.6.11
NARODOWY PROGRAM ROZWOJU HUMANISTYKI

Artykuł powstał w ramach realizacji projektu

badawczego Ekopoetyki historycznych katastrof i konfliktów w literaturze polskiejXXiXXI wieku. Perspektywa porównawcza, finansowanego przez Narodowy Program Rozwoju Humanistyki (nr projektu: $2 \mathrm{aH} 15005683$ ).
W przeciwieństwie do „klimatu”, „zwierząt” czy "mikrobów”, którym w refleksji Bruno Latoura, Dipesha Chakrabarthiego czy Richarda Foltza przyznany został status globalnych aktantów dziejowości, „puszcza" wydaje się milczącym uczestnikiem historii, a także biernym obiektem kulturowych zapisów tego uczestnictwa. O tym, jak mylny to pogląd, świadczyłyby ekokrytyczne lektury dramatów Szekspira, powieści Kiplinga, Doliny Issy Miłosza, Puszczy Antoniego Gołubiewa, Puszczy jodłowej Żeromskiego, czy namysł nad przekazem, towarzyszącym galerii „Las” w warszawskim Muzeum Historii Żydów Polskich POLIN. Refleksje płynące z tej pracy intelektualnej doprowadziłyby nieuchronnie do wniosku, że puszcza jest - fascynującym, wieloznacznym, pochodzącym z praczasów - ekofaktem o latentnej historycznej sprawczości, dysponującym ukrytym, nieco przytłumionym potencjałem symbolicznym, a zarazem wielką siłą oddziaływania na czytelników czy uczestników życia publicznego (jak tego dowiódł polski

\author{
Aleksandra \\ Ubertowska - \\ literaturoznaw- \\ czyni, wykładowca \\ literatury polskiej \\ na Uniwersytecie \\ Gdańskim, obszary \\ jej zainteresowań \\ badawczych to lite- \\ ratura Holocaustu, \\ studia nad pamięcią, \\ ekokrytyka. Swoje \\ artykuły zamieszczała \\ na łamach „Tekstów \\ Drugich, „Pamiętnika \\ Literackiego,","Ruchu \\ Literackiego", w to- \\ mach zbiorowych \\ polskich i zagranicz- \\ nych wydawnictw \\ (m.in. Lexington \\ Books, Peter Lang, \\ Akademie Verlag).
}


przypadek sporów i protestów przeciwko wycince starodrzewu w Puszczy Białowieskiej).

Z punktu widzenia nauki o literaturze „puszcza” wydaje się motywem, czy raczej tematem, narzucającym dość wąskie modele analitycznych aplikacji. Tymczasem właściwa tej figurze ontologiczna rozległość i historyczna trwałość (spaja ona wszak epoki glacjalne z czasami ponowoczesnymi) nadaje jej charakter dyskursu, ruchomego pryzmatu wymiany kulturowej - retorycznie pofałdowanego, wchłaniającego przemiany historyczne, charakteryzującego się proteuszową zmiennością znaczeń. Ponadto puszcza należy - wraz z ogrodem botanicznym ${ }^{1}$, bagnem ${ }^{2}$, plażą, dziką przyrodą/wilderness ${ }^{3}$ - do szczególnego korpusu ekokrytycznych motywów-dyskursów, które łączy zarówno status „resztki”, prehistorycznej pozostałości, czyli „innego” modernistycznej narracji, jak i tendencja do liminalności, łączenia i znoszenia granic kultura-natura, miasto-wieś, arte- i ekofakt. Sytuuje się ona na granicy wielu światów, epok, formacji kulturowych, przypominając człowiekowi o jego archaicznych źródłach, o towarzyszącym mu nieustannie komponencie "dzikości".

Liminalność w nieco innym rozumieniu - bliskim ekokrytyce - sprawia, że puszcza literacka postrzegana być musi jako nieredukowalne do pisma „zewnętrze" tekstu, które jednakże ostentacyjnie usadowiło się w jego wnętrzu, wprowadzając zamęt, ruch oscylacji znaczeń, ostatecznie jednak wymuszające na czytelniku i interpretatorze strategię „ekstraspekcji”, tak postulowaną przez Lawrence'a Buella ${ }^{4}$. Strategia ta zakłada wyzbycie się antropocentryzmu, uznanie realności, naoczności świata natury, z którą literatura pozostaje w relacji konfliktu i nie zawsze konstruktywnego agonu.

1 Zob. J. Beattie, E.D. Melillo, E. O'Gorman Introduction: Eco-Cultural Networks and the British Empire 1837-1945, w: Eco-Cultural Networks and the British Empire: new views on environmental history, ed. J. Beattie E.D. Melillo, E. O'Gorman, Bloomsbury Academic, London-New York 2015, S. 9.

2 R. Giblett Cities and Wetlands. The Return of the Repressed in Nature and Culture, Bloomsbury, London-New York 2016.

3 Por. D. Mazel American Literary Environmentalism, The University of Georgia Press, London 2000, S. 22-25.

4 L. Buell The Environmental Imagination. Thoreau, Nature, Writing, and the Formation of American Culture, The Belknap Press of Harvard University Press, Cambridge Massachusetts 1995, s. 99. 


\section{Puszcza w sieciach ekologiczno-kulturowych}

W takim właśnie poszerzonym porządku status „puszczy” jest dyskutowany w ramach myśli ekokrytycznej. Znakomitym przykładem takiego badawczego podejścia jest kanoniczna monografia Roberta Pogue Harrisona Forests. The Shadow of Civilisation ${ }^{5}$. W ujęciu autora książki puszczę łączą z historią i literaturą wielorakie zależności. Już sama dynamika historii środowiskowej sytuuje puszczę w relacji wrogiej opozycji wobec świata ludzkiego. Jak bowiem przekonująco wywodzi Harrison, kultura neolityczna i cywilizacja pierwszych państw-miast wyłoniła się wbrew napierającej sile pierwotnych lasów, które odrodziły się po ostatnim zlodowaceniu i zmusiły społeczności nomadów do „wyrąbywania” w gąszczu drzew miejsc do osiedlenia. Pozostałości selva antica wyznaczały zawsze skraj, obrzeża kruchej cywilizacji, której groziło ponowne osunięcie się w chaos, dzikość, niezróżnicowanie. Reforestyzacja była więc upiornym wariantem historii, realnie zagrażającym strukturom pierwszych cywilizacji.

Zarazem właściwa puszczy niedystynktywność sprawiła, że pozostała ona niezbywalnym „zewnętrzem” cywilizacji Zachodu, domeną jej projekcji mitycznych, libidalnych, epistemicznych. W puszczy znajdowały schronienie treści zakazane, nieprawomyślne, baśniowe, infantylne, rebelianckie, to tutaj „człowiek dobry stawał się bestią, bezprawie funkcjonowało jako prawo, Rosalinda okazywała się chłopcem, to, co zwyczajne, przekształcało

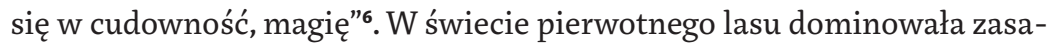
da inwersji, transformacji, rozsadzania zastanych reguł. Wedle Harrisona, właśnie w puszczy cywilizacja Zachodu wyobcowywała się wobec siebie w szczególny sposób, poprzez „autoironię"7, a zatem zaspokajała istotną potrzebę karnawalizacji, nicowania formy, dekonstruowania prowizorycznych uporządkowań. Właśnie ironia jest poznawczą dyspozycją, która zapewnia „narracjom o puszczy” szczególną pozycję w literaturze. Pozwala ona podtrzymywać ambiwalentną pamięć/niepamięć o tym, że ludzkość wprawdzie zwykła definiować siebie jako wspólnotę wygnaną z puszczy (extraforestrial), ale zarazem mgliście pamiętała o tym, że materialność prehistorycznego lasu była - wedle Vico, na którego powołuje się Harrison - fundamentem pierwszych instytucji społecznych: religii, małżeństwa, pochówku zmarłych.

\footnotetext{
5 R.P. Harrison Forests. The Shadow of Civilisation, The University of Chicago Press, Chicago 1992.

6 Tamże, s. V.

7 Tamże.
} 
Labilny kulturowo status puszczy spotęgowały interpretacje teologiczne, chrześcijańskie, upatrujące w niej siedlisko anarchii, pogańskich kultów (o czym zadecydowała ranga lasu w mitologii celtyckiej, germańskiej, wierzeniach ludów słowiańskich). Równocześnie literatura wygrywała przede wszystkim pozycję prehistorycznego lasu jako sceny inwersji, dwuznaczności, konfuzji, maskarady, nieheteronormatywności (Szekspir), medytacji, wzniosłego odosobnienia (Rousseau, Thoreau), ale także aktywnej scenerii dramatycznych wydarzeń historycznych (Las Teutoński, Las Birnam).

Jednostronnie baśniowy wizerunek puszczy, który niewątpliwie dominuje w puszczańskiej bibliotece, domaga się deziluzji, nacięcia epistemicznego, wywracającego sugestię ahistoryczności tej ekoprzestrzeni. Harrison zwraca uwagę na istnienie innego wątku w historii pierwotnego lasu, podkreślając, w jak wielkim stopniu był on domeną ,sfabrykowanej dzikości”, źródłowości ujętej w formę cywilizacyjną, a przede wszystkim w ramy kodeksu własności. Puszcze bardzo wcześnie podporządkowane zostały prawu królewskiemu, które zabraniało eksploatacji, wyrębu, polowań - była to dzikość ekskluzywna, zaanektowana na potrzeby rodziny królewskiej i odstępowana na mocy przywileju wybranym mieszkańcom kraju. Puszcza była więc domeną zakazu, znienawidzonego przez chłopów, pozbawionych odwiecznie im przysługującego prawa do korzystania z zasobów leśnych, była zarazem obiektem pożądania, postulatem często podnoszonym podczas buntów chłopskich.

Wydaje się, że znacznie bardziej radykalny wektor historyczny wprowadza do ekokrytycznego dyskursu o puszczy myśl postkolonialna. Splot metodologiczny postkolonializmu i studiów środowiskowych, pomimo fundamentalnych różnic tych dwóch podejść badawczych ${ }^{8}$, był zresztą silnie obecny już w dziełach klasyków postkolonializmu, od Wyklętego ludu ziemi Franza Fanona9

$8 \mathrm{Na}$ istnienie zespołu różnic pomiędzy tymi metodologiami przekonująco wskazał Rob Nixon, pisząc o hybrydyczności, globalności postkolonializmu i ideałach czystości, pierwotności, regionalizmu, które przyświecają ekokrytykom. Postkolonializm zajmuje się migracją, przemieszczeniem, diasporą, ekokrytyka miejscem, konkretnym krajobrazem, myśl postkolonialna stawia sobie za cel reaktywowanie marginalizowanych, mniejszościowych przeszłości, ekokrytyka zaś operuje pojęciem bezczasowej natury. R. Nixon, Environmentalism and Postcolonialism, w: Postcolonial Studies and Beyond, ed. A. Loomba i in., Duke University Press, DurhamLondon 2005, s. 235-236. ści z podbojem przyrody: „Symbolem wrogiej, podstępnej, nieokiełznanej natury są w koloniach dzikie zarośla, komary, tubylcy i gorączka. Kolonizacja zostaje zakończona w chwili, gdy okiełzna naturę. Tory kolei żelaznej, przecinające dżunglę, wysuszone bagna i gospodarczo- 
przez Kulturę i imperializm Edwarda Saida ${ }^{10}$ po Imperialne spojrzenie Mary Louise Pratt $^{11}$. Podkreślali oni z jednej strony, że kolonizacja jest zawsze w pierwszej kolejności zawłaszczaniem i brutalną eksploatacją konkretnego krajobrazu, który dla rdzennej ludności był nie tylko podstawą utrzymania, lecz także źródłem lokalnych mitów i figurą egzystencjalnego zakorzenienia. Rabunkowe użytkowanie natury uchodziło za pozornie niewidoczną, samooczywistą formę kolonialnej przemocy. Konieczne staje się więc stworzenie metody, która odtworzy symultaniczną relację pomiędzy „losem ludzi i losem świata roślinnego"12, a zatem opisze, praktykowane przez kolonizatorów, sposoby postrzegania wegetacji roślin wyłącznie w perspektywie „submisywnej”,jako zjawiska podporządkowanego kryterium ekonomicznego zysku, jako czystego zasobu.

Równocześnie - i to zagadnienie jest szczególnie chętnie podnoszone przez postkolonialnych ekokrytyków, takich jak Elisabeth DeLoughney ${ }^{13}$, Graham Huggan, Helen Tiffin ${ }^{14}$ - zwracano uwagę na fakt, że biokolonizacja, imperialny podbój dokonywał się najczęściej poprzez tworzenie kompleksowej oświeceniowej „historii naturalnej” (jej książką założycielską była Systema Naturae Karola Linneusza ${ }^{15}$ ), a zatem poprzez produkowanie wiedzy, która przyjmowała formę binominalnych taksonomii, wywłaszczających autochtonów z ram wiedzy natywnej i wprzęgających tę ostatnią w imperialne procesy przemysłowego kapitalizmu. Tłumaczy to częstotliwość pojawiania się postulatów „epistemicznej dekolonizacji”16 podbitych terytoriów, czyli odzyskiwania tubylczych form opisu natury.

-polityczna śmierć mieszkańców podbitego terytorium mają w praktyce to samo znaczenie". F. Fanon Wyklęty lud ziemi, przeł. H. Tygielska, PIW, Warszawa 1985, s. 170.

E.W. Said Kultura i imperializm, przeł. M. Wyrwas-Wiśniewska, Wydawnictwo Uniwersytetu Jagiellońskiego, Kraków 2009.

11 M.L. Pratt Imperialne spojrzenie. Pisarstwo podróżnicze a transkulturacja, przeł. E.E. Nowakowska, Wydawnictwo Uniwersytetu Jagiellońskiego, Kraków 2011.

E. Savory Toward a Caribbean Ecopoetics. Derek Walcott's Language of Plants, w: Postcolonial Ecologies. Literatures of the Environment, ed. E. DeLoughney i in., Oxford University Press, Oxford 2011, s. 81. Zob. E. DeLoughney, G.B. Handley Introduction, tamże, s. 3-43. Zob. G. Huggan, H. Tiffin Introduction, w: Postcolonial Ecocriticism. Literature, Animals, Environment, Routledge, New York 2010.

15 Por. M.L. Pratt Nauka i sentyment (1750-1800), w: tejże Imperialne spojrzenie, s. 22. 
Pierwotnym lasom przysługuje poczesne miejsce w tym nurcie „zielonego postkolonializmu". Książki Vandany Shivy o kolonizacji jako ekologicznym genocydzie, artykuły Lizabeth Paravisini-Gebert ${ }^{17}$ o deforestacji na Karaibach i Jennifer Wenzel ${ }^{18}$ o fundacyjnej roli puszczy w tradycji hinduskiej pokazują, w jak wielkim stopniu ekstensywna wycinka lasów karaibskich, która miała oczyścić tereny pod plantacje kawy i trzciny cukrowej, czy też zagłada lasów deszczowych na Cejlonie poprzedziły procesy pauperyzacji czy eksterminacji rdzennej ludności na tych terenach. Uzasadnione stają się więc postulaty postkolonialnych ekokrytyków, nawołujące do tego, by w opisie imperialnych podbojów w charakterze narzędzia badawczego stosować kategorię "sieci ekologiczno-kulturowych" (eco-cultural networks) ${ }^{19}$, badających wielopoziomowe relacje między ekosystemami a kulturą materialną społeczeństw, czyli ukazujących - to jedynie przykład - sploty zależności pomiędzy brytyjskim rytuałem popołudniowej herbaty, militarno-więziennym reżimem panującym na plantacjach herbaty na Cejlonie i nieodwracalną destrukcją krajobrazu tej wyspy ${ }^{20}$. Puszcza w takim kontekście staje się zatem, trudnym do pominięcia w analizie, „subtekstem narracji o konsolidacji imperialnej władzy w społeczeństwach kolonialnych"21; w poezji Dereka Walcotta czy Pere Labat funkcjonuje zaś jako punkt postkolonialnego oporu, jako przestrzeń utopijnego powrotu do ery przedplantacyjnej.

Warto podążyć za tym kierunkiem myślenia, poszukując inspirujących tropów, wyłaniających się z metodologicznego splotu ekokrytyki i postkolonializmu w literaturze. „Puszcza”, podobnie zresztą jak inne czynniki nieludzkie historii (non-humans), wpisane w siatki i słowniki analityczne

L. Paravisini-Gebert Deforestation and the Yearning for Lost Landscapes in Caribbean Literatures, w: Postcolonial Ecologies, s. 99-117.

J. Wenzel Forests Fiction and Ecological Crises. Reading the Politics of Survival in Mahasveta Devi's „Dhowli", tamże, s. 136-155.

J. Beattie, E.D. Melillo, E. O'Gorman, Introduction: eco-cultural networks..., s. 8. Na temat postkolonialnej orientacji w ramach ekokrytyki zob. również: R. Nixon Environmentalism and Postcolonialism, w: Postcolonial Studies and Beyond, ed. A. Loomba i in., Duke University Press, Durham-London 2005, s. 233-251; G. Huggan, H. Tiffin Postcolonial Ecocriticism. Literature, Animals, Environment, Routledge, New York 2010; M. Banejree Ecocriticism and Postcolonial Studies, w: Handbook of Ecocriticism and Cultural Ecology, ed. H. Zapf, Walter de Gruytar Verlag, Berlin-Boston 2016, s. 194-207.

E.D. Melillo Empire in a Cup: Imagining Colonial Geographies through British Tea Consumption, w: Eco-Cultural Networks...

L. Paravisini-Gebert Deforestation..., s. 100. 
postkolonializmu, w znacznej mierze je komplikują, poddają wielostronnym relokacjom. Wprowadzają zamęt w obrębie opozycji kolonizatorzy - miejscowa ludność, wydobywając utajone znaczenia owych operacyjnych kategorii, które są przecież tak dobrze zadomowione w humanistyce. Za sprawą ujawnienia bytów biomorficznych pojawia się tu bowiem dodatkowy poziom praktyk kolonizacyjnych, który można nazwać „kolonizacją drugiego stopnia”, kiedy to rdzennej ludności przysługuje antropocentryczna sprawczość historyczna i ekonomiczna, puszczy zaś - rola (nie do końca biernego) obiektu podboju.

„Puszcza” jest w dosłownym znaczeniu „tu-bylcza”, bytuje w określonej przestrzeni „od zawsze”, defamiliaryzując pojęcie „tubylca” poprzez ukazanie go jako zleksykalizowanej metafory. Można więc powiedzieć, że przypadku pradawnego lasu mamy do czynienia z fundamentalną pierwotnością, uprzednią wobec antropocentrycznej kategorii „rdzennej ludności”, podrzędnej wobec kultury kolonizatorów, która rościłaby sobie prawa do cywilizacyjnej wyższości.

Osobnym wątkiem, któremu zresztą poświęcę więcej miejsca w kolejnych częściach artykułu, jest praktyka używania retoryki „puszczy” w ramach procedur dehistoryzacji rdzennych narodów, poprzez umieszczanie ich doświadczeń w kontekście natury. Do agendy stereotypów kolonialnych należą wszak „kategorie osadowe, archaiczne, mityczne"22, które są wykorzystywane jako argument za odmawianiem skolonizowanym prawa do posiadania własnej historii. Puszcza pochodzi przecież z tego samego symbolicznego rejestru mitycznej „arche”, jest opisywana jako prastara, uprzednia wobec świadectw historycznych, pomników kultury, form cywilizacyjnych, związanych z istnieniem ludzkiego gatunku. Jak widać, „puszcza” może również posłużyć jako złowieszczy fetysz kolonialnej władzy, element budujący retorykę dominacji i wykluczenia.

Wszystkie te ruchy resygnifikacji, rozszczepiania znaczeń, matowienia pozornej przezroczystości reprezentacji, jakie ujawniają się podczas pisania (o) puszczy, przywodzą na myśl koncepcję języka tubylczego Homiego Bhabhy, przyjmującego formę mówienia w „rejestrze katachrestycznym”, które badacz w innym miejscu swojego wywodu nazywa "głosem Tangeru"23. Właśnie ten

22 H. Bhabha Kwestia innego. Stereotyp, dyskryminacja i dyskurs kolonializmu, w: tegoż Miejsca kultury, przeł. T. Dobrogoszcz, Wydawnictwo Uniwersytetu Jagiellońskiego, Kraków 2010, s. 76. H. Bhabha Postkolonializm i ponowoczesność. Kwestia sprawczości, tamże, s. 196. 
koncept będzie w moim artykule bazą dla namysłu nad statusem puszczy jako ekofaktu i zarazem elementu postkolonialnego dyskursu.

Gło s Ta ng e r u to idea, przejęta przez Bhabhę z pism Rolanda Barthes'a. Autor Przyjemności tekstu za modelowy kontrhegemoniczny język ludów podporządkowanych uznał niezróżnicowany szum, pełen odpadków mowy oświeceniowej, którym rozbrzmiewała przestrzeń targu (suku) w algierskim Tangerze. Jest to zatem odruchowa, naturalna forma wyrażania stanu bycia "mineralnym tłem nowoczesnej dynamiki kolonialnego merkantylizmu"24, by zacytować ponownie Fanona. Czym charakteryzuje się ten model artykułowania doświadczenia kolonizacji? Głos Tangeru to mowa „poza zdaniem” (jako reżimem władzy imperialnej), to język hybrydyczny, niemal niezrozumiały, sytuujący się w szczelinach mowy kolonizatora i zarazem nieustannie kwestionujący jej autorytet. Są to ścinki, niemal odpadki mowy, rozlegające się z różnych źródeł, rozbiegające się w wielu kierunkach, silnie performatywne, powiązane z pragmatyczną sytuacją negocjacji (nie tylko ceny towaru, ale także własnej pozycji historycznej).

\section{Głos Tangeru, dźwięk trembity}

Chciałabym przetestować możliwości, wynikające z połączenia ekokrytyki i postkolonializmu, przykładając terminy, właściwe tym dyscyplinom do lektury cyklu Na wysokiej połoninie Stanisława Vincenza, zwłaszcza pierwszego tomu Prawda starowieku - tekstu, który semy „praboru”, ,starego lasu kiedrowego", ,głuszy staroniedźwiedziej” oplatają niczym kłącza, wycinając w nim poziomy znaczeń i osie procesów semiotyzacyjnych. „Puszcza” jest słowem uprzywilejowanym w słowniku Vincenza, w eposie huculskim przypisano mu wiele, często zaskakująco oryginalnych synonimów. Również w porządku morfologii tekstu opis puszczy umieszczony został w pozycji inicjalnej niczym funkcja „bereszit/genesis” opowieści o początku świata; dopiero w dalszej kolejności z „niezróżnicowanego chaosu” puszczy wyłaniają się historie wspólnot i huculskich bohaterów.

Genealogia mieszkańców Huculszczyzny, jaka wyłania się z trylogii Vincenza jest ściśle powiązana z puszczą - archaicznym praborem, autonomicznym wobec człowieka ekosystemem splecionych z sobą form istnienia. Sposób, w jaki Vincenz pojmuje ontologię puszczy, zbliża go do ujęć wpółczesnych ekologów i praktyków leśnictwa, zwłaszcza autora cenionych książek

24 F. Fanon Wyklęty lud ziemi, s. 31. 
Petera Wohllebena ${ }^{25}$. Wedle Vincenza Huculi to "naród połoński”, definiujący się poprzez organiczny związek z ziemią, to także „lud puszczy”, potomkowie zbiegów, tułaczy, wygnańców, żyjących poza obrębem prawa cesarskiego w harmonii z lasem, który jawi się jako niedostępny, niepoznawalny, pochodzący z praczasu ${ }^{26}$.

Już od Kraśnego Łuhu szło się ku Czarnohorze lasami nigdzie nieprzerzedzonymi, nieruszanymi toporem. Coraz przepastniejsze były głębiny leśne, coraz bardziej bezbrzeżne, coraz trudniej było zboczyć ze ścieżki cłowej. Wszędzie zawory z kłód, gąszcze, jamy i wądoły, bezdroża nieprzebyte. Lasy ciche, głusze poważne, bez śladów zwierzyny nawet, bez śladu innego, jak życie lasu i umieranie lasu. Lasy w bezczasie zatopione, nie wiadomo, kiedy powstały i końca nie oczekiwały, nie obawiały się. [...]

Pod samą już Czernyhorą, gdy rodzina i służba Szumiejowa zbliżała się do swojej połoniny, wchodzili w najstarszy las: półspróchniały basztarnik. Sędziwe jedle basztowe, tak tęgie i grube jak dobre siana, odziane w sute warstwy mchu jakby w kożuchy smokowe. Był to las odwieczny, z pierwowieku niepokonany, smokowy. A sprzężony przeciw obcym natrętom nie puszczał do wnętrza nikogo, ani małych, ani wielkich gości. Nawet wicher nie miał tam dostępu. Nawet dla nowych pokoleń drzew nie było tam miejsca. Jedno drzewo trzymało tam drugie, jedno zżyło się z drugim. Nawet zmurszałe już drzewa utrzymywały równowagę. Każdy spróchniały konar coś podtrzymywał, czemuś służył, znaczył coś w prawiekowej zgodzie. ${ }^{27}$

25 Tak Wohlleben opisuje stan zrównoważonego lasu: „Miarą dobrostanu drzewa jest bowiem dobrostan otaczającego go lasu. [...] Ich dobrostan zależy od całej społeczności i gdy znikają te rzekomo najsłabsze, wówczas giną także pozostałe. Las traci zwartość, gorące słońce i porywiste wiatry mogą teraz hulać aż do samej ziemi i zmieniać wilgotno-chłodny klimat. Silne drzewa również parokrotnie w życiu zapadają na różne choroby i w takiej sytuacji są zdane na wsparcie słabszych sąsiadów. Jeśli ich zabraknie, wystarczy nieszkodliwe porażenie owadami, żeby przypięczętować nawet los gigantów". P. Wohlleben Sekretne życie drzew, przeł. E. Kochanowska, Otwarte, Kraków 2016, s. 27.

O nowatorskim pojmowaniu przez Vincenza "historii wypływającej z krajobrazu”, która to teoria wydaje się pionierska wobec współczesnej geografii humanistycznej pisze Jacek Kolbuszewski w artykule Stanisława Vincenza czytanie krajobrazu. „Na wysokiej połoninie”, w: Studia o Stanisławie Vincenzie, red. P. Nowaczyński, Wydawnictwo KUL, Lublin-Rzym 1994.

27 S. Vincenz Na wysokiej połoninie, pasmo I: Prawda starowieku. Obrazy, dumy igawędy z wierchowiny huculskiej, Pogranicze, Sejny 2002, s. 71. 
Ta korelacja pomiędzy historią ludzi i lasu znajduje potwierdzenie w mikrohistoriach, ilustrujących dzieje huculskiej wspólnoty; być może najbardziej znamienna jest tu historia Foki Szumiejowego, barwnego bohatera literackiego o rysach pikarejskich, którego pradziadek, jak głosi legenda, został odnaleziony w dziupli drzewa i wychowany przez bezdzietną parę pasterzy. Huculi, jak powiada autor Zwady, tak jak ród Foki, „z drzew się wywodzą”; ta biomorficzna genealogia staje się w trylogii Vincenza fundamentem ich osobistych wolności i totemicznym znakiem etnicznej tożsamości. Drzewa towarzyszą Hucułom w wielu obszarach życia, pełnią funkcję budulca, narzędzi, źródła form mitycznych, wreszcie nośnika pierwotnej wiedzy o świecie.

Życie Foki przypada na przełom dwóch formacji cywilizacyjnych: starowieku (pierwowieku) i nowowieku, kiedy to rozpoczęły się wyręby lasu na skalę przemysłową (tzw. „butyny”) ${ }^{28}$. Dopiero inwazja kapitalistycznych form eksploatacji zasobów natury wymusiła na Hucułach uregulowanie kwestii własności - wcześniej, w okresie starowieku „puszcza należała do samej siebie", a funkcję prowizorycznych granic pełniły działy wód. Brak respektu wobec prawnie rozumianej własności ziemi związany był z magicznym stosunkiem do puszczy. Huculi otaczali kultem drzewa; ich użytkowaniu, czyli wycince dla celów gospodarczych, towarzyszył rytuał wyrębu „drzew-przyjaciół”, respektujący budowę pni drzewnych i rozkład konarów. Mieszkanie w chacie zbudowanej wedle tego rytuału porównywano do bezpiecznego „zamieszkiwania w drzewie”, egzystencjalnego współbytowania z biosferą, otaczającą świat ludzki. „Prawda starowieku pisze Vincenz - to podstawa i dzieje tej niewidzialnej wspólnoty, to styl domostw-korzeni"29.

Kulturę starowieku znamionował silny, konsekwentny fonocentryzm. Huculi wierzyli, że „nie w piśmie prawda, lecz w głosie”. Dlatego też przekazem historycznym są w eposie Vincenza opowieści wieszczunów, oralne podania, poddane rytmice języka mówionego, podzielone na sekwencje wieczornych

28 Gwałtowne przemiany cywilizacyjne, prowadzące do rozbicia autarkicznej, odseparowanej od świata kultury Hucułów, zapoczątkowała budowa w połowie XIX wieku traktu Krattera drogi łączącej Karpaty Wschodnie z Węgrami, a także drogi z Kołomyi do Kosowa, traktu kolejowego ze Lwowa przez Stanisławów do Czerniowiec. Równie niszcząco jak masowa deforestacja wpłynęło na krajobraz Huculszczyzny odkrycie złóż ropy naftowej w tym regionie. Zob. J.A. Choroszy Obudzić ducha kupieckiej zarobkowości, w: tegoż Huculszczyzna w literaturze polskiej, Wrocławska Drukarnia Naukowa, Wrocław 1991, s. 100-112. 
biesiad. „Pańskie pismo” to przywilej obcych, cudzoziemców; jest opisywane jako zjawisko niesłychanie egzotyczne, ale też jako obiekt nieufnego oglądu, epistemicznej podejrzliwości. Nad Czeremoszem istniało jednak osobliwe pismo, pismo puszczy - w Vincenzowskim cyklu wielokrotnie pojawiają się wzmianki o tym, że puszcza przemawia do Hucułów w tajemniczym, nieprzezroczystym kodzie. Jego zapośredniczonym śladem okazują się wszechobecne „karby”, wycinane na kłodach drewna, zapisujące reguły mówionego prawa, „rewaszu”. To osobliwe „pismo klinowe” zachowuje właściwości leśnego drzewa; nośnikiem treści semantycznych są tu tyleż porowatość kory, co konieczne zranienie, nacięcie, biegnące w poprzek włókien drzewnych. Pismo to jest siecią „dobrych traum” - huculskie „karby” są określane jako „dobre dla drzewa", przechowują bowiem ich dziedzictwo w innym, bardziej umownym i symbolicznym porządku. Deponują przekaz puszczy w formie materialnego archiwum, które pośredniczy pomiędzy biosferą i światem ludzi.

W pozycji ekwiwalentu pisma puszczy usytuowana zostaje również „trembita" - rytualny instrument, wykonany z potężnego konara świerku. Trembita wedle wierzeń Hucułów „ściąga strunę wiatrową od nieba do ziemi” ${ }^{\text {”o }}$, wiąże odrębne porządki świata, które jawią się w codziennym doświadczeniu jako całkowicie od siebie odseparowane. Semiotyzacja doświadczenia dokonuje się w świecie Hucułów właśnie poprzez zaśpiew muzyczny, dźwięk trembity. Strukturyzuje on czas świąt i pracy pasterskiej, wyznacza punkt harmonijnej równowagi pomiędzy żywiołami "pioruna, lasu, szumu wód”31 i dzięki temu otwiera dostęp do porządku metafizycznego.

Narracja w cyklu Vincenza odwzorowuje kłączowaty, „nawietrzny” bieg dźwięku trembity. Przybiera ona formę rozczepiających się, zanikających i ponownie wyłaniających się wątków i pasm opowieści: biografii Foki, podań o „swobodzie”, czyli subkulturze leśnych opryszków, listów z tomu Nowe czasy, wreszcie ekomorficznych, zatopionych w archaicznych początkach historii o puszczy. Jest to narracja zawiła, nieciągła, jak gdyby nawarstwiająca się w sposób nieprzejrzysty i nierównomierny. Można postawić tezę, że tu właśnie ujawnia się postulowany przez Barthes’a i Bhabhę głos Tangeru - rodzima narracja, hybrydyzująca pokusę homogenicznej opowieści kolonialnej władzy. Co znamienne, tubylcza autonarracja jest organicznie związana z drzewami i lasem, definiuje siebie jako głos puszczy. 
Głos Tangeru znosi również Vincenzowską, talmudyczno-borgesowską metaforę „lewej i prawej strony tekstu” ${ }^{\text {32 }}$. Ta figura, przywołująca erudycyjne asocjacje, przeciwstawia sobie porowatą, zbitą stronę przekazu, pełną supłów, kołtunów, zapętleń i jego treść esencjonalną, doskonale przezroczystą, dostępną jedynie wybranym. U Vincenza szorstkość zrostu różnych przebiegów narracyjnych, który Józef Olejniczak nazywa „niezgrabnościami stylistycznymi"33, nacina podmiotowość mitu o początku, nie pozwala mu zastygnąć w samooczywisty fetysz kolonialny, który w ostatecznym rozrachunku ustawiłby autochtonów w pozycji podporządkowanej.

Opowieść o puszczy nie jest u Vincenza ekologiczną idyllą, opisywaną poprzez dostępne pastoralne konwencje przedstawienia - przed tą wizją chronią ją chropowatość, szorstkość splotu tekstowego i nieoczywiste treści kolonialnego dyskursu. Puszcza jest dostępna w narracji jedynie do pewnego stopnia, wydaje się częściowo nieopowiadalna, niepodatna na semiotyzację, dlatego zastyga w nierównych, porwanych artykulacjach. Stylistyka pastoralna dominuje jedynie we fragmentach, opisujących dwór w Krzyworówni (głównie w pierwszym tomie Prawda starowieku). Posiadłość polskiego dziedzica ukazana została jako azyl dla oswojonych dzikich zwierząt (niedźwiedzia i rysia), a także jako miejsce biesiadnych spotkań z tubylcami (gazdami z połonin i rodziną żydowskiego arendarza Etyka). Widoczna staje się tu ambiwalencja postaw: z jednej strony empatycznego, afektywnego stosunku do miejscowej ludności, z drugiej zaś przyjęcia wykładni historycznej, korzystnej dla kultury dominującej, przedstawiającej Karpaty Wschodnie jako ostoję tolerancji i pokojowego współżycia wielu narodów.

Stosunki narodowe i ekonomiczne na Huculszczyźnie niezupełnie odpowiadają klasycznym rozróżnieniom, wprowadzonym do humanistyki przez myśl postkolonialną, jednak z pewnością pozwalają się opisać jako „osad-



Tamże, s. 238-241.

J. Olejniczak Metafizyka Arkadii. Szkic o twórczości Stanisława Vincenza, w: tegoż Arkadia i małe ojczyzny. Vincenz - Stempowski - Wittlin - Miłosz, Oficyna Literacka, Kraków 1992, s. 120.

E.W. Said Kultura i imperializm, s. 5. kolonialną, jaką formułuje w swojej książce na temat Ukrainy Zachodniej Daniel Beauvois, kładąc nacisk na skłonność polskich pisarzy i memuarystów do przedstawiania Ukrainy jako „obszaru mitu historycznego i egzotyki". Zob. D. Beauvois Trójkąt ukraiński. Szlachta, carat i lud na Wołyniu, Podolu i Kijowszczyźnie 1793-1914, przeł. K. Rutkowski, Wydawnictwo UMCS, Lublin 2005, s. 12. 
w którym „stawką jest terytorium i posiadłości, geografia i władza”36. Nie sposób jednak nie zauważyć, że czytając Prawdę starowieku trudno odpowiedzieć na pytanie, kto w tym świecie jest kolonizatorem, a kto kolonizowanym. Odautorski narrator zajmuje pozycję pozornie nieokreśloną, labilną, $\mathrm{w}$ istocie jednak zacierającą nieuchronne w układzie kolonialnym różnice klasowe i ekonomiczne napięcia. Konflikty te trzeba mozolnie odtwarzać, wydobywając na powierzchnię lektury pojedyncze, pozornie zdawkowe zdania („panowie potrafią zniszczyć wszystko”" $)$. Dobrotliwy, szpakowaty dziedzic (jego pierwowzorem był dziadek pisarza, Stanisław Przybyłowski) nazywa siebie „pierwszym gazdą górskim”), podobnej formuły („my, dzieci gór"38) używa narrator. Gdy wniknąć bliżej w ten aspekt huculskiej epopei, powstaje wrażenie, że jest to bardzo podstępna konstrukcja podmiotowości, w istocie przywłaszczająca sobie atrybucję tożsamościową rdzennej ludności, gest protekcjonalny, arbitralnie znoszący granice pomiędzy kolonizatorem i tubylcem (czy aby za jego zgodą?). Wyparte, zaprzeczone granice odradzają się jednak w różnych rejestrach tekstu, przybierając zakamuflowaną formę ${ }^{39}$; ujawniają się jako marginesy epickiej opowieści lub pozornie nieistotne budowle, rekwizyty, przestrzenie.

W tym kontekście dwuznaczny sens zyskuje konsekwentna archaizacja "narodu połonińskiego", wiązanie Hucułów z obszarem starodrzewu, najbardziej pierwotnej puszczy karpackiej. Celem tego zabiegu wydaje się wtórna naturalizacja Huculszczyzny i, w konsekwencji, jej dehistoryzacja. W świetle tej hipotezy pozorną niekonsekwencją może się wydawać przybieranie przez narratora maski „człowieka puszczy”, niemal identyfikowanie się z nim. To „pragnienie prymordialności” zdradza prawdziwą kondycję narratora: obsesja źródłowości, pierwotności i wszystkich przywilejów z tym związanych może pojawić się jedynie w horyzoncie kolonizatora - reprezentanta kultury pisma, kartografii, kodeksu prawnego.W istocie, wydaje się ona eskapizmem,

36 Tamże.

37 S. Vincenz Na wysokiej połoninie, pasmo II: Nowe czasy, Instytut Wydawniczy PAX, Warszawa 1982, s. 411.

S. Vincenz Prawda starowieku, s. 25.

Taka "koncyliacyjna” wykładnia całego cyklu dominuje w opracowaniach poświęconych twórczości Vincenza. Por. J.A. Choroszy Atlantyda słowiańska, w: tegoż Huculszczyzna w literaturze polskiej, s. 292-311; M. Klecel Na przełomie czasów. Mit i historia w cyklu Vincenza "Na wysokiej połoninie", w: Studia o Stanisławie Vincenzie, s. 125-146; R. Łużny Vincenz a kultura ludowa Rusinów, tamże, s. 201-214; J. Olejniczak Metafizyka Arkadii, w: tegoż Arkadia i małe ojczyzny. 
unikiem przed podjęciem w opowieści drażliwych kwestii własności, dominacji, ekonomicznego wyzysku, która nieuchronnie zespalałaby się z tematem brutalnej eksploatacji puszczy, ingerującej w rzeźbę terenu, rozrywającej spójność pierwotnych ekosystemów.

Dzisiejszemu wędrowcowi, czy mieszkańcowi gór naszych, co napatrzył się na przemysłowe wyręby leśne, tzw. butyny, na te ry zy przedziwne, to jest koryta i łożyska drewniane do spuszczania ściętych kłód z gór, na te mygły olbrzymie, to jest stosy bierwion, poukładane nad rzeką do spławu, na daraby, czyli tratwy długie, wiązane łykiem, a kierowane przez junackich kiermanyczów, wywijając się śmiało po zakrętach i skaczące z wodospadów Czeremoszu, na te haci, czyli wodospory, tworzące całe zapasy wody jakby jeziora - każdemu, kto widział tę całą wielikańską pracę, pełną niebezpieczeństw i potęgi - trudno sobie wyobrazić góry huculskie bez tego wszystkiego. W dodatku, jak się to nieraz powtarza i słyszy, niemała część ludności w pewnych okresach żyje z butynów, ze spławiania drzewa.

Tymczasem jest to rzecz wcale nowa. I z wyrębami lasów zaczyna się nowy okres. Nic tak nie zmieniło oblicza kraju i krajobrazu, nic tak nie zmieniło dawnej niedostępności jego, a także gospodarczych zajęć, przyzwyczajeń, potrzeb, jak te wyręby przemysłowe. ${ }^{40}$

Kwestia prywatyzacji „,bożego lasu”, którą przynosi „nowowiek”, domagałaby się zmiany stylu i metody diagnozowania zjawiska, spoza baśniowo-gawędziarskiej dominanty stylistycznej tomów Vincenza. Częściowo postulat ten zaspokaja bardziej realistyczny ton kolejnych pasm, zwłaszcza Nowych czasów. Jednak, co znamienne, opis zmian krajobrazu, brutalnego zniszczenia starodawnej rzeźby terenu i przede wszystkim wycinki splecionych z sobą kilkusetletnich drzew, grzybów, mchów nie ustanawia wyłomu w dominującej tonacji cyklu, przeciwnie, płynnie wpisuje się w ramy quasi-naturalnej historii regionu. Zanika tu pytanie o sprawczość w kontekście katastrofy ekologicznej, jaką spowodowała deforestacja, o ekonomiczny obieg wartości i wyzysku tubylczych zasobów. Ukrycie się za maską rodzimego gawędziarza może być interpretowane w tym kontekście jako unik, ominięcie kwestii kolonialnej odpowiedzialności i określenia pozycji, jaką wobec niej zajmuje polski pisarz. 
Postawa narratora, realizującego „ekumeniczną", wielokulturową strategię autora, przywodzi na myśl paradoksalną poetykę Jądra ciemności i rozbieżne punkty widzenia Marlowa, tak jak je interpretuje Edward Said w swojej książce Kultura i imperializm. W Prawdzie starowieku, tak jak w odczytaniu autora Orientalizmu, narrator, niezależnie od swoich intencji, nie jest w stanie pisać z pozycji całkowicie zewnętrznej wobec dyskursu kolonialnego, staje się zatem wcieleniem narratora, który - jak powiada Said - „wiele wyklucza, nawet wówczas, kiedy wydaje się włączać i konsolidować"41.

Kwestia własności (i jej naruszania) okazuje się zabłąkanym znaczącym, spoza porządku ekonomicznego. Ujawnia się ona w aporiach (krypto)kolonialnego tekstu, reliktach klasowej przemocy, ukrytych pod pozorem idylli. Taką właśnie funkcję pełni "motyw wędrujący” Vincenzowskiego cyklu o Huculszczyźnie - kamienny areszt, służący do przetrzymywania rysia i niedźwiadka, a niegdyś do więzienia zbuntowanych chłopów (o czym napomyka się zdawkowo, bagatelizując to traumatyczne dziedzictwo mieszkańców karpackiego regionu). W motywie kamiennego aresztu zbiegają się wszystkie istotne ekologiczne subteksty Prawdy starowieku: archaiczność miejscowej przyrody ożywionej i nieożywionej, jej niepodatność na reprezentację, a zarazem postępująca nieuchronnie domestykacja „dzikości”, przekształcanie jej w przestrzenie użytkowe, w narzędzia służące podbojowi terytorium i ekonomicznemu podporządkowaniu miejscowej ludności.

Narrator, choć pozornie udziela głosu Innemu, a nawet przyznaje mu prymat w narracji, w istocie reprezentuje panoramiczną perspektywę, ,zszywającą" rozbitą opowieść tubylców, zacierającą niespójność głosu Tangeru (częściowo broni się przed tą homogenizującą praktyką leksem „puszczy”). Jeśli przyjąć tezę Harrisona, mówiącą o tym, że puszcza jest domeną ironii, to ulokowanie jej w punkcie splotu/zrostu ekokrytyki i postkolonializmu powinno przybierać formę ruchu rozpleniania się wieloznaczności, nieustającej wymienności znaczeń. W polskim kontekście splatają się w tym ruchu rozpleniania: historia polskiej pańszczyzny, wywłaszczenia z prawa do użytkowania puszczy, ułomna nowoczesność, traktująca prastary las jak czysty zasób, podlegający masowej deforestacji, wreszcie rozproszone opiłki narracji kolonialnej. 


\section{Abstract}

\section{Aleksandra Ubertowska}

UNIVERSITY OF GDAŃSK

Writing the Jungle: Economies of Ecocritical and Postcolonial Discourses

Based on the literary motif of the jungle, Ubertowska examines the potential of combining two research perspectives - ecocriticism and postcolonial theory. Drawing on the work of Robert Harrison, Edward Said and Lawrence Buell, she treats 'the jungle' as a polyvalent discourse that changes in time, and that is rooted in many'ecological and cultural networks. The methodology elaborated in the first part is applied in the second part, where Ubertowska explores Stanisław Vincenz's Hutsul-cycle On the High Uplands.

\section{Keywords}

Stanisław Vincenz, ecocriticism, environmentalism, postcolonialism 